\title{
Sea sandwort from Surtsey: chromosomal evidence of active evolution via wide-hybridization
}

\author{
KESARA ANAMTHAWAT-JÓNSSON ${ }^{1}$, AUDREY PACE ${ }^{1}$ AND SIGURĐUR H. ÁRNASON ${ }^{1,2}$ \\ ${ }^{1}$ Institute of Life and Environmental Sciences, School of Engineering and Natural Sciences, University of Iceland, Sturlugata 7 , \\ Reykjavík 102, Iceland. ${ }^{2}$ Westfjord Iceland Nature Research Centre, Adalstræti 12, 415 Bolungarvík, Iceland. \\ Corresponding author: Kesara Anamthawat-Jónsson, kesara@hi.is
}

\begin{abstract}
Sea sandwort (Honckenya peploides) was among the first species of vascular plants colonizing Surtsey. It is a member of the carnation family, Caryophyllaceae, a coastal plant with circumpolar distribution. The species is dioecious comprising separate female and hermaphrodite (male) plants. Our previous study of this plant revealed high molecular polymorphism, indicating rapid expansion and multiple origins, but low genetic differentiation, suggesting gene flow on Surtsey. The maintenance and/or expansion of populations with high gene diversity on the island are most likely fostered by several factors, one of them being the polyploid nature of the study species providing fixed heterozygosity. We therefore investigated chromosome number diversity of $H$. peploides from Surtsey, in comparison with accessions from Heimaey and other locations within and outside Iceland. Seeds were germinated with and without cold stratification. Chromosomes were isolated from root tips using the cellulase-pectinase enzymatic squash method. DAPIstained chromosomes were counted from microscopic images that were taken at 1000x magnification. The results show that the most common $2 n$ somatic chromosome number of this species is $68(2 n=4 x=68)$, but a tetraploid cytotype with 66 chromosomes also exists. The karyotype analysis shows that the species is an autotetraploid, most likely originating via chromosome doubling (whole genome duplication) in a diploid ancestor. Numerous other $2 n$ numbers were discovered, from the diploid number $2 n=2 x=34$ in Heimaey to several different numbers between 40 and 64 . The triploid hybrid numbers $2 n=3 x=51(50-52)$ were discovered from both Surtsey and Heimaey, as well as from other regions. Triploid hybrids serve as a bridge promoting gene flow within populations, promoting heterozygosity in the tetraploid species. All other numbers are aneuploids, most likely deriving from back-crossing of triploid hybrids and the euploid parents. The presence of aneuploids across the species distribution range is due to its ability to propagate asexually by clonal expansion. The presence of the lower ploidy levels within species, together with the extensive aneuploidy, may be an evolutionary characteristic of a pioneering plant, with great dispersal ability and genetic diversity, such as sea sandwort.
\end{abstract}

\section{INTRODUCTION}

Sea sandwort [Honckenya peploides (L.) Ehrh.] was among the first four species of vascular plants to colonize Surtsey in 1965-1967, while the island was still in the last phase of cooling down (Friðriksson
1964; Magnússon et al. 2009). The other three species are sea rocket (Cakile arctica Pobed.), sea lymegrass [Leymus arenarius (L.) Hochst.] and sea bluebells [Mertensia maritima (L.) Gray]. As the 

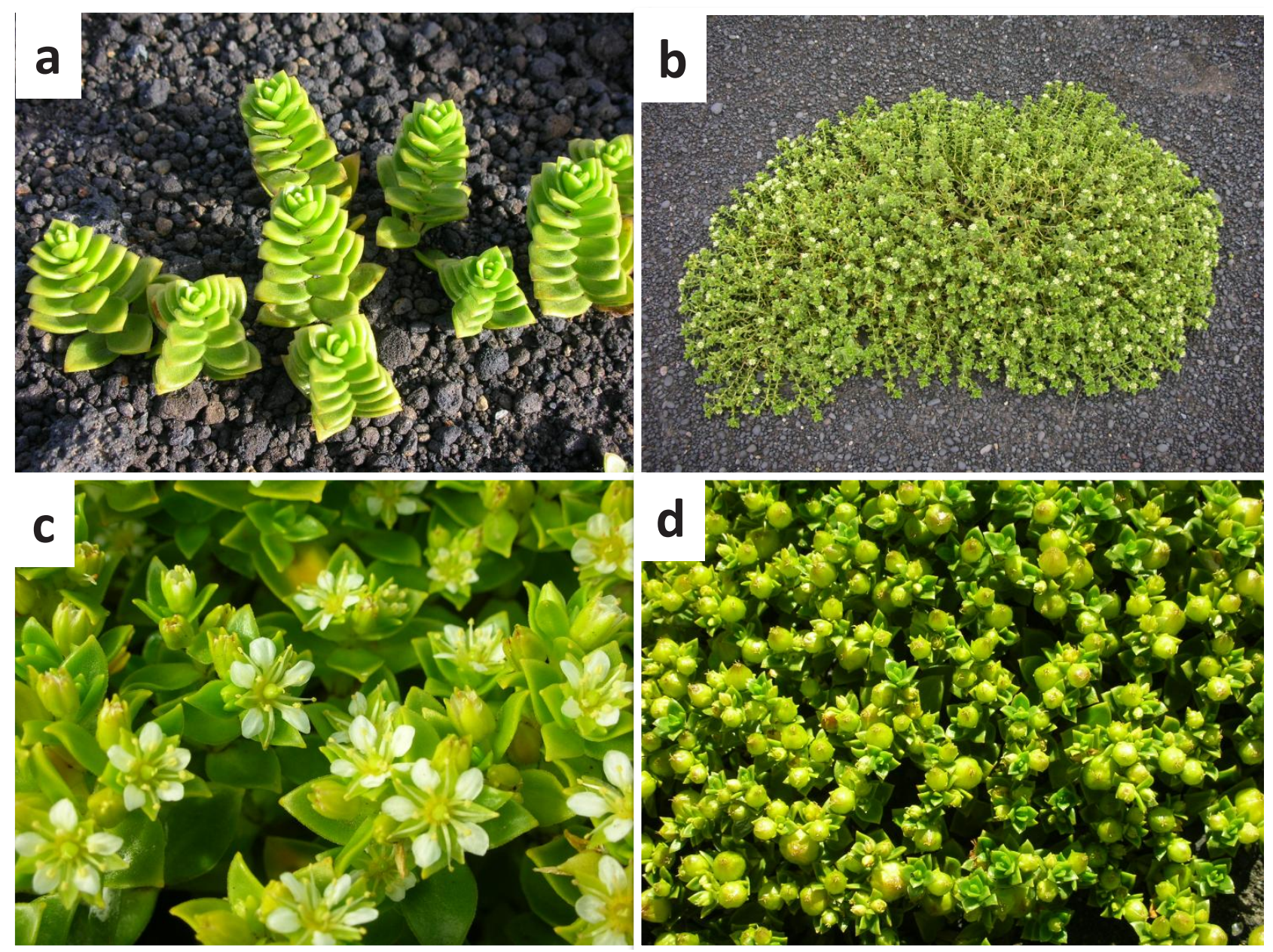

Figure 1. Sea sandwort (Honckenya peploides) from Surtsey: (a) young individual plants; (b) fully grown plant in a clonally expanded mat; (c) hermaphrodite flowers showing large petals; and (d) female flowers showing fruit capsules. Photographs by K. AnamthawatJónsson, July 2010.

common names imply, they all are coastal plants that colonized the island by means of seed dispersal by sea (Magnússon et al. 2014). Since the colonization, H. peploides has become the most abundant plant on the island and is a key facilitator of plant and animal colonization, providing substrate binding for plants as well as nesting material for birds (Sigurdsson \& Magnússon 2010).

Honckenya peploides (Fig. 1) is the only species within the genus Honckenya (L.) Ehrh., belonging to the subfamily Alinoideae in the carnation family Caryophyllaceae. The species has a subdioecious reproductive system, consisting of pistillate (female) plants producing capsules and staminate (male) plants delivering pollen (Malling 1957). The pistillate flowers have a normally developed gynoecium, small petals and non-functional, staminodie-like (aborted) anthers. They produce capsules $6-10 \mathrm{~mm}$ in size with large seeds. Staminate flowers, on the other hand, have short styles, larger petals and welldeveloped anthers, producing pollen grains. Some of these staminate flowers have the ability to produce capsules with low seed numbers and are therefore categorized as hermaphrodites. Hermaphrodite seeds develop into female and hermaphrodite plants, in an approximate 1:3 ratio, whereas seeds of female flowers produce about as many hermaphrodites as females (Malling, 1957). The sex determination system is heterogamous for the hermaphrodite.

Both female and male (hermaphrodite) plants coexist, but the proportion between the two sexes varies among locations. Philipp \& Adsersen (2014) found that populations on the southern coast of Iceland had around equal numbers of pistillate and staminate plants, whereas on Surtsey they found pistillate plants predominating, presumably due to their higher water stress tolerance. Sanchez-Vilas \& Retuerto (2017) found that the females of $H$. peploides on 
the Galician coast of Spain had greater water use efficiency than the males. This ability is likely to help maintain high rate of photosynthesis in waterlimited conditions, as a female needs to allocate more of its biomass to reproduction. Sexes of dimorphic species often differ in ecophysiological traits and display spatial segregation, and in an evolutionary context, gender specialization appears to be favored in resource-poor environments (Delph \& Wolf 2005). Surtsey is a good example - its gender specialization is towards the female sex. Resources especially during the early colonization stages were probably limited due to poor substrate conditions of the sand and the lava/tephra soil. In addition, Philipp \& Adsersen (2014) found a tendency towards a higher frequency of hermaphrodite plants on Surtsey with a higher number of seeds per capsule compared to populations on the south coast and the nearby island of Heimaey. They suggested that this arises from the time right after the colonization of Surtsey, when population size was small and the small generalist pollinators were not able to deposit sufficient pollen on pistillate plants, causing the hermaphrodites to have an advantage by being able to set seed after selfing. The result of this initial advantage of the hermaphrodites in combination with the inheritance of the sexes can still be seen due to the longevity of individual plants.

Honckenya peploides reproduces both sexually and asexually (clonal via rhizomes) and displays a large amount of genetic variation within populations in north-western Spain (Sánchez-Vilas et al. 2010), Greenland and Svalbard (Eithun 2003), and on Surtsey itself (Árnason et al. 2014). An experimental study of Australian seagrass (Posidonia australis Hook.f.), a predominantly clonal plant, has demonstrated that a higher level of genetic diversity can benefit the species due to the increased likelihood of those populations having genotypes that can persist under environmental change (Evans et al. 2017). As with $H$. peploides we have found a significantly higher level of genetic diversity among island and coastal populations in Iceland (including Surtsey) compared to that of mainland Europe (Árnason et al. 2014), which is opposite to the general pattern of oceanic island biogeography (Whittaker et al. 2008, Frank 2010). The large genetic variation found in $H$. peploides on Surtsey (and nearby locations) is therefore likely to be an advantage in the ecological context.
Our molecular analysis of $H$. peploides (Árnason et al. 2014) has indicated several factors that likely foster the maintenance and/or expansion of populations with high gene diversity on Surtsey. One of these factors is the plant itself. The subdioecious breeding system of the plant causes poor seed set after self-fertilization in the hermaphrodite plants (Tsukui \& Sugawara 1992, Eithun 2003), thus reducing inbreeding due to selfing. Although the frequency of seed set by hermaphrodite plants on Surtsey was not as low as predicted, it was still far more inferior to the fertility of the female plants (Philipp \& Adsersen 2014). Another important factor promoting high gene diversity within a population is the polyploid nature of a species providing fixed heterozygosity (Soltis $\&$ Soltis 2000). The aim of the study reported here was therefore to explore the polyploidy nature of H. peploides.

Genetic variation is often maintained through fixed heterozygosity in polyploid species. Fixed heterozygosity has been reported in a number of polyploid arctic plants and seems to be the norm rather than the exception. Brochmann et al. (2004) found that all Svalbard polyploids were genetic autopolyploids with fixed heterozygosity at isozyme loci. Furthermore, they found that heterozygosity increases dramatically from diploid to high-level polyploids in 65 arctic taxa. This high level of heterozygosity has been proposed by other authors to be the motive force behind polyploidy expansion into new habitats (Levin 2002, Soltis et al. 2015). Brochmann et al. (2004) speculated that fixedheterozygosity as a result of polyploid formation, buffering against inbreeding and drift (environmental filtering), is the cause of the great evolutionary success of polyploids in the arctic region. Out-crossing diploid populations tend to become genetically homogeneous when confronted with bottlenecks and inbreeding, as is often the case when colonization of isolated areas takes place (Aguilar et al. 2008, Yuan et al. 2012). In fact, ecological modeling generally supports patterns of adaptive niche differentiation in polyploids, with young polyploids often invading new niches and leaving their diploid progenitors behind (Baduel et al. 2018). Typical arctic plant populations (usually autopolyploids) have the possibility of retaining genetic variation due to fixed allelic diversity within each individual (Otto \& Whitton 2000). The deposit of ancestral genetic material into duplicated genomes guarantees that genetic diversity is maintained 
Table 1: Published chromosome numbers for Honckenya peploides.

\begin{tabular}{lll}
\hline Location & Source & $2 \mathrm{n}=$ \\
\hline Spitsbergen, Svalbard & Flovik (1940) & 66 \\
Dragor, Denmark & Malling (1957) & 68 \\
Sakhalin Island, Russia & $\begin{array}{l}\text { Sokolovskaya \& } \\
\text { Strelkova (1960) }\end{array}$ & $66,68,70$ \\
Wrangle Island, Russia & Agapova (1993) & $66,68,70$ \\
North Eastern Russia & Zhukova (1966) & 68 \\
Eastern Russia & Zhukova (1966) & 66 \\
Moneron Island, Russia & Probatova (2004) & $34 *$ \\
North Eastern Asia & $\begin{array}{l}\text { Zhukova (1966) } \\
\text { Ogotoruk Creek, N.W. }\end{array}$ & $\begin{array}{l}\text { Johnson \& Packer } \\
\text { (1968) }\end{array}$ \\
$\begin{array}{l}\text { Alaska } \\
\text { Meade River, N. Alaska }\end{array}$ & $\begin{array}{l}\text { Packer \& McPherson } \\
\text { (1974) }\end{array}$ & 68 \\
Western Alaska & Murray \& Kelso (1997) & 68 \\
Arctic Canada & Löve \& Löve (1982) & 68 \\
Arctic circumpolar & $\begin{array}{l}\text { Löve \& Löve (1975) } \\
\text { Iceland }\end{array}$ & $66,68,70$ \\
Löve \& Löve (1950, & ca. 40, 66 \\
1956) & $\begin{array}{l}\text { Lövkvist and Hultgård } \\
\text { (1999) }\end{array}$ & 68 \\
\hline
\end{tabular}

* indicates diploid.

despite intense inbreeding, bottlenecks and drift, associated with long distance seed dispersal events or re-colonization of recently barren areas (Soltis et al. 2015).

Honckenya peploides is a tetraploid species with a relatively high chromosome number $(2 \mathrm{n}=4 \mathrm{x}=66,68$, 70) (Table 1) and a large genome (mean $4.33 \mathrm{pg} / 1 \mathrm{C}$ ) when compared to other members of Caryophyllaceae
(Kapralov et al. 2009; Leitch et al. 2019). Four subspecies of $H$. peploides have been identified (Jonsell 2001): subsp. peploides, distributed from northern Norway to northern Portugal; subsp. diffusa (Hornemann) Hultén ex V.V. Petrovsk, which has circumpolar distribution, mainly in Arctic and northern Boreal zones; subsp. major (Hooker) Hultén, found in the Northwest Pacific area and on the coasts of north eastern Russia down to Japan; and subsp. robusta (Fernald) Hultén, found in northeastern North America. According to Hultén (1971), subsp. diffusa is a variety of subsp. peploides and therefore we have combined their distribution in the location map of the present research (Fig. 2). Subsp. peploides sensu Hultén occurs mainly in the northern parts of Norway, Svalbard, Greenland, Iceland and subarctic Canada (Houle 1997; Jonsell 2001). In Iceland (Kristinsson et al. 2018), H. peploides can be found on most shorelines from sea level up to $50 \mathrm{~m}$ above sea level, with Surtsey being the only place where the plant can be found growing up to $100 \mathrm{~m}$ above sea level. Studies from several locations across the whole of the species range report varying tetraploid chromosome numbers, $68 \pm 2$ (Table 1; Rice et al. 2015), but one report includes the diploid number $2 n=2 x=34$ from an eastern Russian island location that harbors the subsp. major (Probatova et al. 2004).

Two types of chromosome number variation have been documented for $H$. peploides (Table 1): ploidy variation (diploid $2 n=34$ versus tetraploid $2 n=68$ ) and aneuploidy, the number variation within ploidy level,

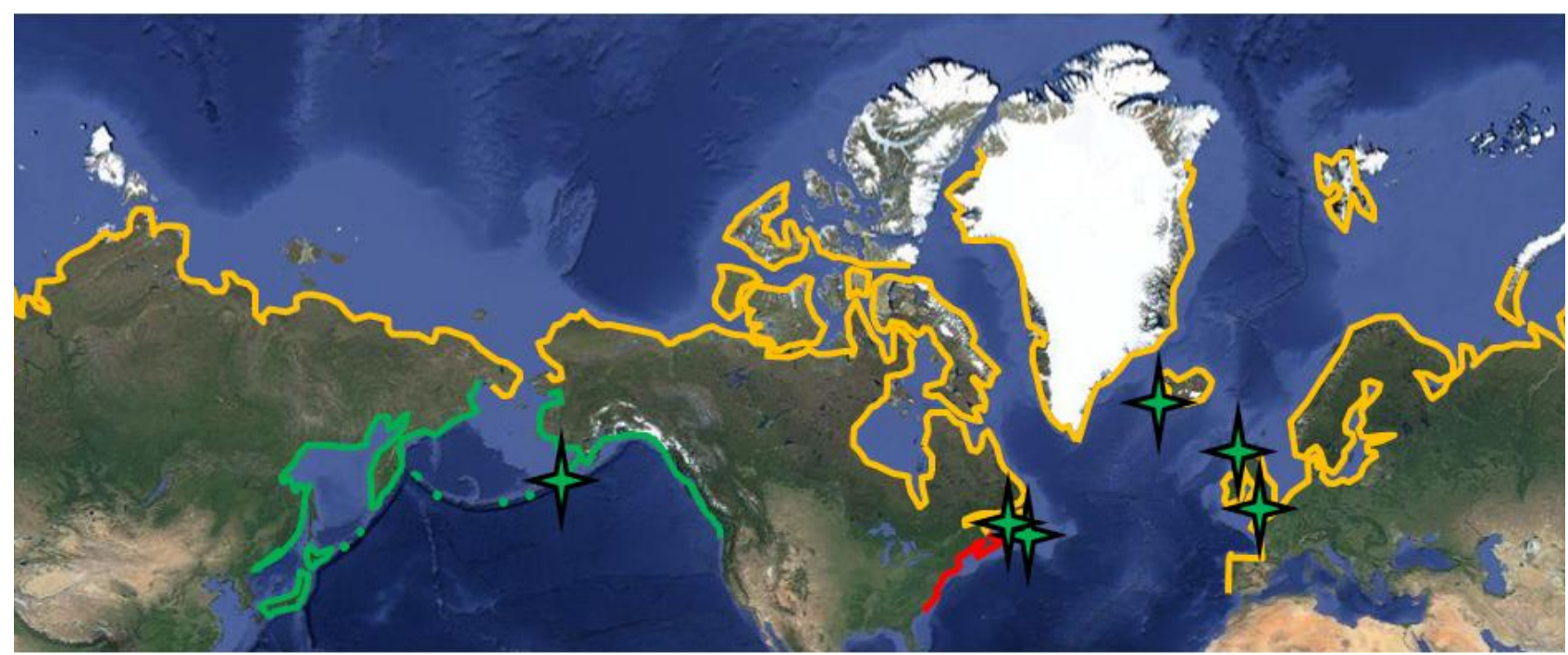

Figure 2. Map of distribution of Honckenya peploides and its subspecies: subsp. peploides (yellow); subsp. major (green); and subsp. robusta (red). Stars represent collection locations. From east to west: (1) Keibu, Estonia and Kolobrzeg, Poland; (2) Cornwall, England and Maryport, Scotland; (3) Iceland (Surtsey, Heimaey, Stokkseyri and Seltjarnarnes); (4) Madeleine Island, Canada; (5) Miquelon Island, Canada; and (6) Cold Bay, Alaska. Map modified from Google Earth. 
in this case a variation of the tetraploid number (66 and 70). Intraspecific chromosome number variation is wide-spread especially among arctic-alpine plants (Löve \& Löve 1975, Al-Shehbaz \& O'Kane 2002, Brochmann et al. 2004, Grundt et al. 2005, Peruzzi et al. 2012). These include Arabidopsis arenosa (L.) Lawalree (Brassicaceae), which has $2 \mathrm{n}=16,18,28$, 32, 34, 39, 40 (Al-Shehbaz \& O'Kane 2002), and Barnardia japonica (Thunb.) Schult. \& Schult.f. (Hyacinthaceae) with $2 \mathrm{n}=16,18,26,27,34,35$, 36, 43 (Haga \& Noda 1976), to name a few. These intraspecific karyotype variants have been termed cytotypes or cytoraces (Stuessy 2009). Some even suggest that various reproductively isolated cytotypes within species may indeed represent cryptic species (Soltis etal.2007). Intraspecific cytotypes can be found allopatrically, parapatrically or in mixed populations. Major courses generating cytotypic variation include hybridization, intraspecific polyploidy, chromosomal rearrangements and dysploidy (Stebbins 1971, Levin 2002, Baduel et al. 2018, Mandakova \& Lysak 2018).

The relationship between intraspecific variation in chromosome number and variation in physiological, morphological or life history characteristics remains largely unexplored. In some cases, karyotypic variations result in no apparent phenotypic difference between cytotypes as significant gene flow is maintained (Ramsey et al. 2008). In other cases, modest karyotypic variations have yielded morphological distinctions, for example in floral and fruit characteristics, as is the case of buttercup (Ranunculus L.) (Cires et al. 2009), which in turn can affect pollination and pollinator species (Thompson \& Merg 2008) and flower sex (as in crowberry (Empetrum L.), Suda et al. 2004). In Honckenya, seed germination of $H$. peploides subsp. major (subspecies containing diploid plants) occurred within three weeks at temperatures at least $28^{\circ} \mathrm{C}$ without prior cold stratification (Voronkova et al. 2011a). However, seeds of the tetraploid $H$. peploides began to germinate only after cold stratification (Baskin \& Baskin 2001). Variation in morphology can also be seen between H. peploides in Greenland, Svalbard and Norway, with the Svalbard ecotypes being generally smaller in all traits measured (M. Philipp, pers. comm.). Such information are useful when attempting to explain these cytotypic differences in the context of ecological preferences and evolutionary adaptation of the sea sandwort in Iceland.
The aim of this study was to find some evolutionary trends in karyotype diversity of $H$. peploides and to distinguish possible variations on a subspecies level. This was achieved by determining chromosome numbers of plants from the young island of Surtsey (57 years old), the older island of Heimaey (over 10 000 years old), and from several other locations across the northern hemisphere. This study may shed light onto the origin and evolution of the species - a major aspect of plant conservation - whilst contributing to the thorough studies that have been performed on the island of Surtsey.

\section{MATERIALS AND METHODS \\ Plant material}

All but one $H$. peploides accessions in this study (Table 2) were raised from seeds. Hp-02 from Seltjarnarnes peninsula is the only accession that was grown from plants collected in the field in September 2012. Live plants of this accession were placed into plastic containers with the native substrate and kept initially at $15^{\circ} \mathrm{C}$ under a grow lamp with a $12 / 12$ light/dark regime. Seeds from all other locations in Iceland were collected in July 2010 together with plant samples for the molecular study of Árnason et al. (2014).

Seed samples were collected from diverse locations on Surtsey, from the low elevation areas located on the northern sand spit, around the eastern slopes and in the vegetation-rich gull colony on the southern side of the island, to the high elevation areas around the western crater Surtungur and on the steep east-facing slope of the crater Surtur. Samples from Heimaey were from Stórhöfdi on the south side of the island and by the harbor in the northern part. Samples from the mainland location Stokkseyri on the southern coast were collected from plants growing by the sea on glacial deposits and fine sand, at the end of a freshwater marsh in between two large glacial rivers.

In order to obtain plant material spanning the worldwide distribution of the species, a correspondence with multiple research institutions around the globe was initiated by the author SHÁ. Through this connection, seeds of $H$. peploides were obtained from both Europe and North America (Fig. 2, Table 2). Locations in Europe include Kolobrzeg, Poland (Hp-16); Keibu, Estonia; Cornwall, England; and Maryport, Scotland. North American locations are Miquelon Island, Canada (Hp-06); Madeleine Island, Canada; and Cold Bay, 
Table 2. List of accessions of Honckenya peploides, sample locations and obtained $2 \mathrm{n}$ somatic chromosome numbers. Chromosome groups: A (66-68); B (60-64); C (54-58); D (50-52); E (44-48); F ( 40); G (34). Numbers in bold are of cells shown in Figs 3 and 4.

\begin{tabular}{|c|c|c|c|c|}
\hline Location (see also Fig. 1) & Accession & 2n number & 2n group & Figure \\
\hline Surtsey, Iceland & Нp 08 & $68, \mathbf{6 8}+\mathbf{2 B}$ & A & Fig. $4 \mathrm{a}$ \\
\hline \multirow{4}{*}{$63^{\circ} 18^{\prime} 10.80^{\prime \prime} \mathrm{N}, 20^{\circ} 36^{\prime} 16.92^{\prime \prime} \mathrm{W}$} & Hp 09 & $68,60 / 62, \sim 51$ & $\mathrm{~A}, \mathrm{~B}, \mathrm{D}$ & \\
\hline & Hp 21 & $44 / 46,48$ & $\mathrm{E}$ & Fig. 4b \\
\hline & Hp 29 & $68+1 B, 62+2 B, 60$ & A, B & \\
\hline & Hp 30 & $60 / 62,58$ & $\mathrm{~B}, \mathrm{C}$ & \\
\hline Heimaey, Iceland & Hp 01 & $\mathbf{6 8}, 66,55$ & A & Fig. 4c \\
\hline \multirow[t]{6}{*}{$63^{\circ} 26^{\prime} 15.64^{\prime \prime} \mathrm{N}, 20^{\circ} 16^{\prime} 02.36^{\prime \prime} \mathrm{W}$} & Hp 04 & $>44$ & $\mathrm{E}$ & \\
\hline & Hp 05 & $68,60 / 62,51$ & $\mathrm{~A}, \mathrm{~B}, \mathrm{D}$ & Fig. 4d \\
\hline & Hp 07 & $58,51+2 B, 50,34$ & $\mathrm{C}, \mathrm{D}, \mathrm{G}$ & Fig. $4 \mathrm{e}$ \\
\hline & Hp 19 & $66 / 68, \sim 60, \sim 40$ & $\mathrm{~A}, \mathrm{~B}, \mathrm{~F}$ & \\
\hline & Hp 25 & $\sim 68,62,58$ & A, B & \\
\hline & Hp 27 & $56+$ & $\mathrm{C}$ & \\
\hline Stokkseyri, Iceland & Hp 11 & $\mathbf{6 8}+\mathbf{1 B}, 66$ & A & Fig. 4f \\
\hline $63^{\circ} 50^{\prime} 16.01^{\prime \prime} \mathrm{N}, 21^{\circ} 03^{\prime} 34.05^{\prime \prime} \mathrm{W}$ & Hp 17 & $\sim 60,56$ & $\mathrm{~B}, \mathrm{C}$ & \\
\hline $\begin{array}{l}\text { Seltjarnarnes, Iceland } \\
64^{\circ} 09^{\prime} 19.48^{\prime \prime} \mathrm{N}, 22^{\circ} 00^{\prime} 10.58^{\prime \prime} \mathrm{W}\end{array}$ & Hp 02 & 68 & A & Fig. 3 \\
\hline \multicolumn{5}{|l|}{$54^{\circ} 17^{\prime} 00.57^{\prime \prime} \mathrm{N}, 16^{\circ} 09^{\prime} 45.79^{\prime \prime} \mathrm{E}$} \\
\hline \multicolumn{5}{|l|}{$47^{\circ} 04^{\prime} 32^{\prime \prime} \mathrm{N}, 56^{\circ} 22^{\prime} 46.61^{\prime \prime} \mathrm{W}$} \\
\hline \multicolumn{5}{|l|}{$55^{\circ} 12^{\prime} 00.27^{\prime \prime} \mathrm{N}, 162^{\circ} 42^{\prime} 47.25^{\prime \prime} \mathrm{W}$} \\
\hline \multirow{2}{*}{$\begin{array}{l}\text { Unknown (Madeleine Island, Canada/ Cornwall, England/ } \\
\text { Maryport, Scotland/ Keibu, Estonia) }\end{array}$} & Hp 13 & $54+, 44 / 46$ & $\mathrm{C}, \mathrm{E}$ & \\
\hline & Hp 28 & 50 & $\mathrm{D}$ & \\
\hline
\end{tabular}

Alaska (Hp-10). This Alaskan accession presumably belongs to subspecies major (Fig. 2), whereas all other accessions in the present study are from the main subspecies peploides/diffusa.

\section{Seed stratification, sterilization and germination}

Seeds of $H$. peploides obtained from the various locations (Fig. 2, Table 2) were split into two groups, those to undergo stratification and those to be germinated right away. For each accession, one half was stratified by placement into plastic bags with a moist, sandy medium and refrigerated at 2 $-4^{\circ} \mathrm{C}$ for 12 weeks. The other half was sterilized right away using the procedure described below and placed into the germination chamber directly after. Seeds that had been stratified for up to 12 weeks as well as those that were germinated right away were sterilized in $1 \% \mathrm{CL}$ solution for $2 \mathrm{~min}$, then rinsed with distilled water and placed in a Petri dish between two sterile filter papers. Petri dishes were then placed under a $12 / 12$ light regime at $15^{\circ} \mathrm{C}$ during light hours and then moved into a dark refrigerator and kept at $5^{\circ} \mathrm{C}$ during dark hours until germination. Germination success was estimated visually and noted as $\%$ germination per plate. Once germinated, five seedlings from each accession were placed in pots with a mixture of sand and soil. All plants were maintained and grown under 16/8 light/dark regime at $20^{\circ} \mathrm{C}$ in the Plant Genetics research laboratory growth room located on the second floor of Askja the Natural Sciences building at the University of Iceland, Reykjavík.

\section{Enzymatic root tip squash method of chromosome preparation}

Enzymatic root tip squash was performed according to Anamthawat-Jónsson $(2001,2010)$. Young root tips were harvested from the live plants at mid-day. Root tips were cut to approx. $1-2 \mathrm{~cm}$ and placed in $15 \mathrm{~mL}$ tubes with ice water which were kept on ice at $4^{\circ} \mathrm{C}$ for $27 \mathrm{~h}$. This was done in order to synchronize mitosis and arrest as many cells as possible in metaphase. Root tips were then placed in another 15 $\mathrm{mL}$ tube containing fixative solution of a $1: 3 \mathrm{v} / \mathrm{v}$ ratio of glacial acetic acid and 96\% ethanol. They were allowed to be in this fixative at room temperature for about two hours before keeping them in a freezer at $-30^{\circ} \mathrm{C}$ until use. 
To prepare chromosome slides the fixed root tips were submerged in a citrate buffer $(0.1 \mathrm{M}$ citric acid monohydrate, $0.1 \mathrm{M}$ trisodium citrate dehydrate, distilled water) for 20 min to dilute off the fixative. The buffer was replaced once during this period of time. Root tips were then placed one at a time onto acid-cleaned slides, which had been washed in chromium trioxide in $80 \%$ sulphuric acid for at least 3 hours, rinsed thoroughly and then stored in $96 \% \mathrm{EtOH}$ in a refrigerator. The root tips were then trimmed down, leaving only the tip (1 - $2 \mathrm{~mm}$ ) containing the meristematic tissue on the slide. The buffer droplets around the root tip were carefully removed with tissue paper and a 19 $\mu \mathrm{L}$ drop of enzyme mixture containing pectinase (Sigma P7416, 30 units $/ \mathrm{mL}$ ) and cellulase (Merck 1.0232, Onozuka R10, 80 units $/ \mathrm{mL}$ ) was added to each slide. The root tips were placed in the incubator at $37^{\circ} \mathrm{C}$ for $9-10 \mathrm{~min}$ for digestion. After incubation the enzyme was reduced with tissue paper. A drop of acetic acid (45\%) was added, reduced with tissue paper, and then another drop was added. After resting for 5 min the drop was reduced and re-applied once more. The size of the drop was reduced before extracting the cells under the stereo-microscope. This was achieved by teasing the cloudy meristem tissue above the root cap with a needle and tweezers, releasing the meristem cells into the acetic acid suspension. Surplus root tissue was removed, and the suspension slightly mixed with a needle. The needle and tweezers were cleaned in $70 \%$ ethanol in between applications. A clean coverslip was placed on the slide and gently tapped vertically with a needle to scatter the cells. By manually pressing the cover slip firmly between sheets of filter paper the cells were squashed. The coverslip was removed after freezing the slide on dry ice or in liquid nitrogen. The slides were stored in dark and cool place until use.

Prepared slides were stained with $20 \mu \mathrm{L}$ of the DAPI (1 $\mu \mathrm{L} / \mathrm{mL})$ (4 ',6-diamidino-2phenylindole), a fluorochrome that binds to AT-rich regions of DNA, and viewed under a Nikon Eclipse E800 epifluorescence microscope using a UV filter block with 340-380 excitation and 430-450 emission wavelengths (blue). The images obtained with the $100 \mathrm{x}$ objective (total magnification $\mathrm{x} 1000)$ were captured with a Nikon Digital Camera DXM1200F and used for chromosome number determination. Karyotype construction was made from the best images, following Levan et al. (1964).
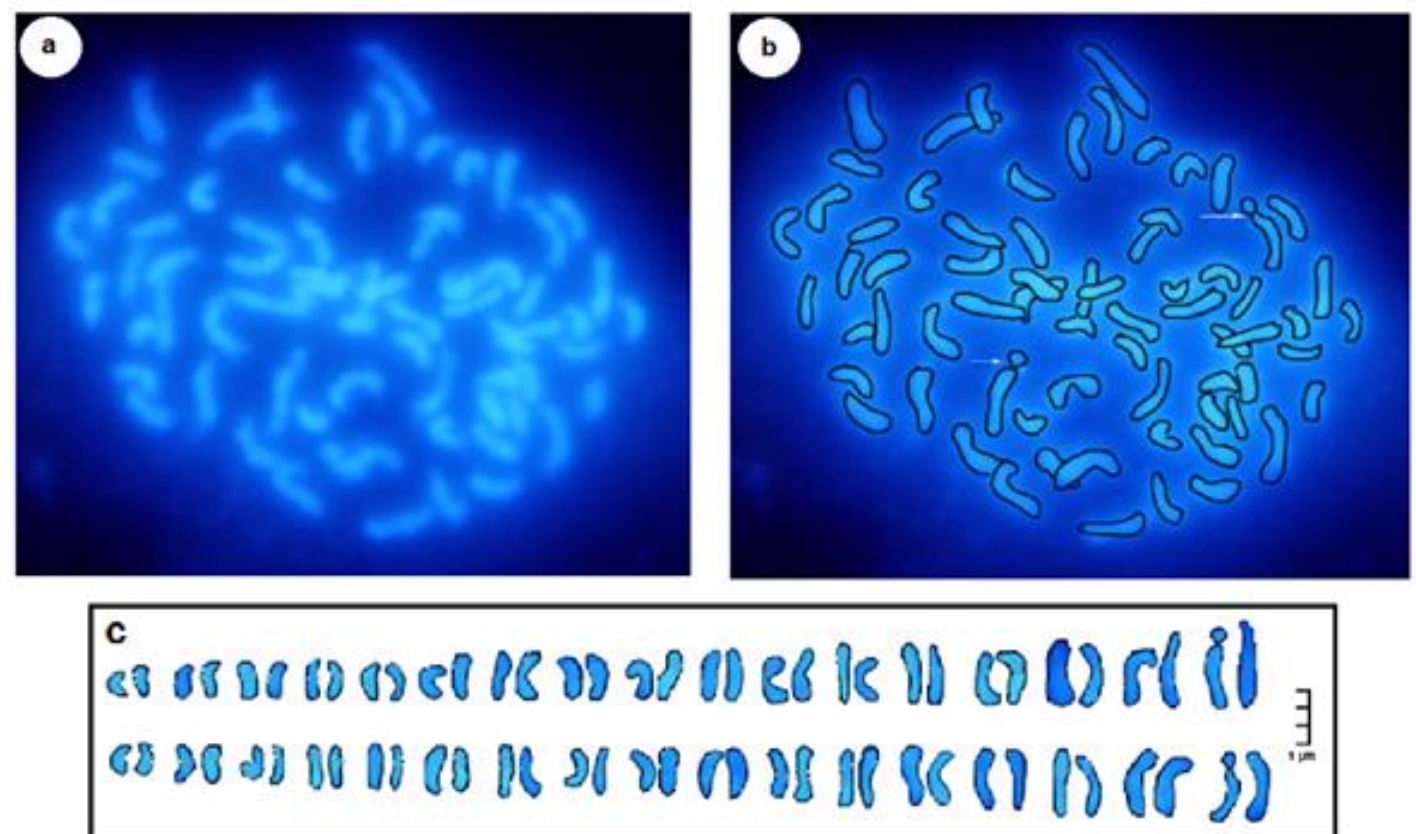

Figure 3. Honckenya peploides chromosomes from Seltjarnarnes (accession Hp-02), stained with DAPI taken at 1000x magnification, showing a full tetraploid complement of 68 chromosomes (a), the same chromosomes outlined for pixel size measurement (b), and karyotypically arranged according to relative sizes and morphology (c). Arrow indicates location of satellite, the secondary constriction of NOR bearing chromosome. 

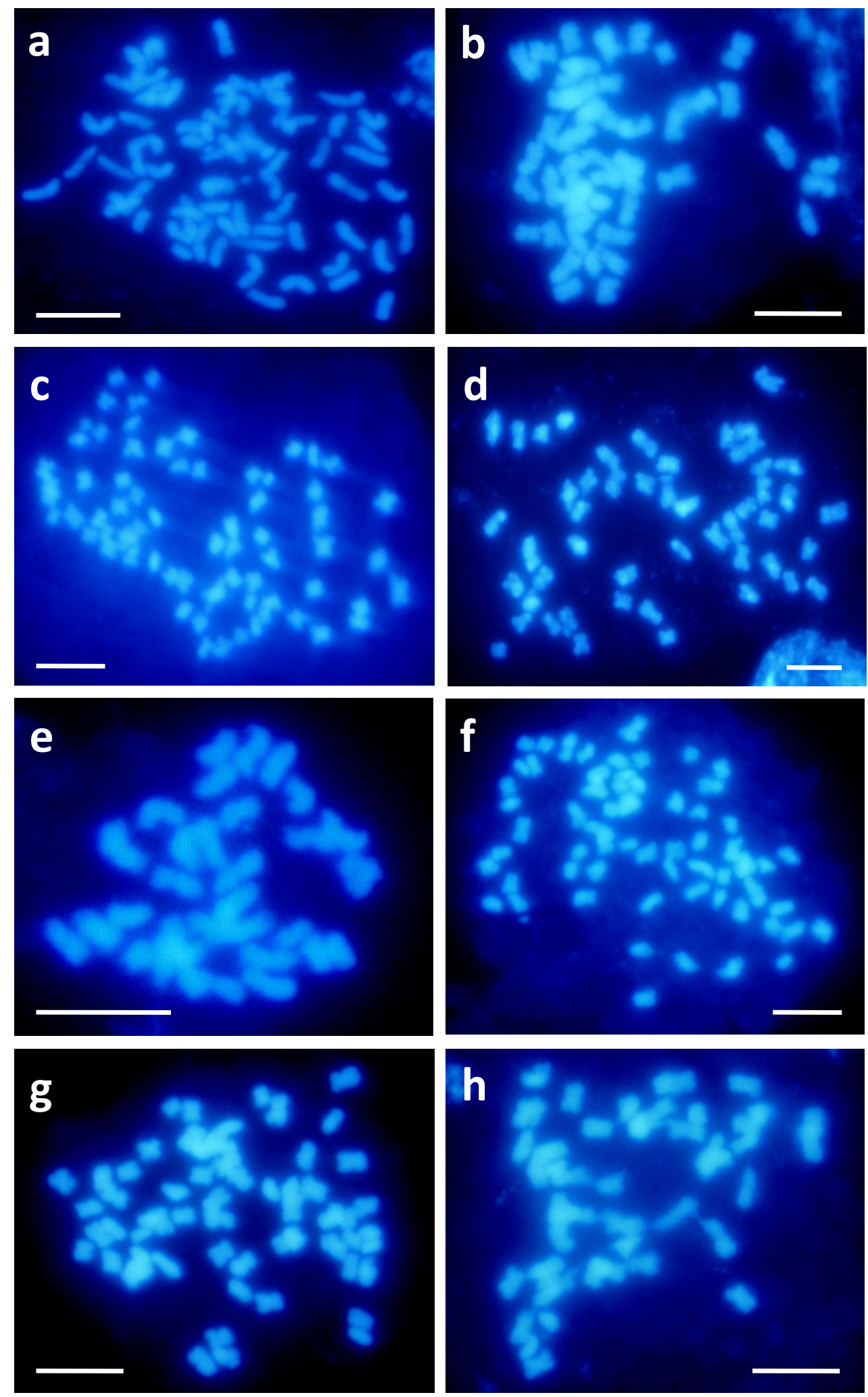

Figure 4. Metaphase cells of Honckenya peploides from different accessions showing 2 n somatic chromosome numbers (see also Table 2): (a) Hp-08 from Surtsey with $2 n=68+2 B s$; (b) Hp-21 from Surtsey with $2 \mathrm{n}=48$; (c) Hp-01 from Heimaey with 2n=68; (d) Hp-05 from Heimaey with $2 \mathrm{n}=51$; (e) Hp-07 from Heimaey with $2 n=34$; (f) Hp-11 from Stokkseyri with $2 \mathrm{n}=68+1 \mathrm{~B}$; (g) Hp-16 from Poland with $2 \mathrm{n}=68$; and (h) Hp-10 from Alaska with $2 n=44$. Scale bars represent $5 \mu \mathrm{m}$.

\section{RESULTS AND DISCUSSION}

Ecophysiological differences at subspecies level The present study shows an example of physiological differences in Honckenya peploides at subspecies level. It was tested whether seeds obtained from the various locations outside of Iceland required cold stratification to germinate. Seeds from each accession were split into two groups, those to undergo cold stratification and those to be germinated right away. Prior to germination, with or without stratification, the seed samples were surface sterilized with bleach. The sterilization procedure proved effective at removing most bacterial, mould or fungal contaminants from the seed coat as only $7.1 \%$ (22 
of 311) of the Petri dishes containing germinating seeds were contaminated. Of the unstratified seeds, only the samples obtained from Cold Bay, Alaska (H. peploides subsp. major), germinated under the $12 / 12,5^{\circ} \mathrm{C} / 15^{\circ} \mathrm{C}$ conditions, with most germination occurring within five to seven days. None of the seeds obtained from other locations, which belonged to the subspecies peploides/diffusa, germinated without prior cold stratification. Germination rates following cold stratification for 12 weeks were quite high, with roughly an $80 \%$ germination rate in all the non-contaminated plates at $12 / 12,5^{\circ} \mathrm{C} / 15^{\circ} \mathrm{C}$. These results appear to be in good agreement with previous reports on plants from Kamchatka Peninsula in the Russian Far East (Voronkova et al. 2011a, 2011b), whereby $H$. peploides subsp. major could germinate without prior cold stratification, in the same way as many secondary plant species that succeed the pioneer plants on volcanic substrates. Furthermore, closely related plant species that have the same life history and ecological preferences have different requirements for stratification. For example, the white Rhododendron aureum Giorgi requires cold stratification, while seeds of the co-existing red species (Rh. camtschaticum Pall.) can germinate spontaneously (Voronkova et al. 2011b). Seed dormancy has a genetic basis.

Cold stratification is commonly used for breaking seed dormancy in plants. However, the effects of cold stratification on dormancy release and its physiological characteristics have only been investigated in model species or crop plants. The model plant Arabidopsis thaliana (L.) Heynh. which grows in extreme environments, such as on geothermal soil in Iceland (Mandakova et al. 2017), will not flower without cold stratification. The plant hormone gibberellin (GA) is best known to stimulate developmental transitions including seed germination, flowering, and the transition from juvenile to adult growth stage. In Arabidopsis, GA has been shown to break seed dormancy and is required for normal development of seedlings (Hauvermale et al. 2020). Seed dormancy is a critical mechanism that delays germination until environmental conditions are favorable for growth. Plant hormones gibberellin (GA) and abscisic acid (ABA) have long been recognized as key players in regulating dormancy and germination. A gene expression study of seed germination in rice has shown that cold stratification results in a rapid increase of GA and IAA (auxin) promoting germination, and, at the same time, in a rapid decrease of ABA that has a role in dormancy maintenance (Yang et al. 2019). Recent data have shown that brassinosteroid (BR) hormones also promote germination by activating GA downstream genes and inactivating ABA signaling (Kim et al. 2019). A proteomic study of seed dormancy release has shown a significant increase in expression of numerous genes that are involved in the respirationrelated metabolism processes, biosynthesis of amino acids, and translation during the dormancy release of a citrus species after cold stratification $\left(4^{\circ} \mathrm{C}\right)$ or gibberellin (GA) treatment (Lu et al. 2018). Pioneer species, such as $H$. peploides colonizing Surtsey or any barren and open localities, have a better chance of survival and establishment as their seeds can only germinate after cold stratification (and vernalization) during the preceding winter months, not germinating readily after seed maturation before winter.

\section{Most accessions of Honckenya peploides are} tetraploid with $2 n=4 x=68$

The tetraploid somatic chromosome number $2 n=4 x=68$ is the most common number for H. peploides from Surtsey, Heimaey, and other coastal regions in the North Atlantic (Table 2, Figs. 3, 4a, 4c, $4 \mathrm{f}$ and $4 \mathrm{~g}$ ). This is the most common chromosome number of $H$. peploides samples world-wide (Table 1) and is the number representing all subspecies in the Chromosome Count Database (CCDB, Rice et al. 2015). Furthermore, the present study also shows accurate count with a karyotype of metaphase chromosomes (Fig. 3). To the best of our knowledge, no karyotype of Honckenya has been published elsewhere. The karyotype was constructed based on pixel size of DAPI-stained chromosomes (Figs. $3 a$ and $3 b$ ) and the sizes were sorted and paired with possible homologs after chromosome morphology (Fig. 3c). Chromosome sizes ranged from $1.36 \mu \mathrm{m}$ $-4.66 \mu \mathrm{m}$ while most seem to be metacentric and sub-metacentric chromosomes.

The karyotype (Fig. 3c) reveals two pairs of NORs (Nucleolar Organizing Region) on the largest chromosomes of the complement, although sometimes only one of each pair appears to be actively transcribing, seen as secondary constriction (arrows in Fig. 3b). NORs in a polyploidy species are often variable in size - some are easily detectable as in Fig. 3b, while others are not. This is known to be due to variation in copy numbers of ribosomal (rDNA) 
repeats, resulting from deletion or amplification at preferential sites over an evolutionary time (Pederson 2011). In addition, not all NORs are active. The major 18S-26S ribosomal genes in the NOR are tandem repeats comprising hundreds or thousands of copies, in ample excess of what would be required to sustain cellular ribosomal synthesis (Rogers \& Bendich 1987). Therefore, the number and size of nucleoli in nuclei at interphase are often variable, as some are more active than others. The nucleolus is the site of ribosomal RNA synthesis, i.e. rDNA transcription and rRNA maturation, and ribosome production (McKeown \& Shaw 2009). The number of nucleoli in plants has been positively correlated with the ploidy level (Leven 2002; Kim et al. 2015). In the present study we found interphase nuclei with two to four nucleoli in the tetraploid accessions.

The karyotype constructed in the present study (Fig. 3) indicates that the species is an autotetraploid, comprising two sets of the homologous diploid chromosome complement. Although several cytological mechanisms are known to induce polyploidy in plants, including somatic chromosome doubling, the most probable route of autopolyploidy is via hybridization of unreduced (2n) gametes of diploid parents from different populations within a species (Leitch \& Bennett 1997, Ramsey \& Schemske 1998), reinforced by reproductive isolation between the diploids and the newly formed tetraploids. Major crop plants of the world are polyploid, for example, wheat, maize, potatoes, banana, cotton, oilseed rape, and coffee beans. Increasing the ploidy level is known to be positively correlated with plant production, both biomass and yield (Leitch \& Leitch 2008). But in the ecological and evolutionary context, genome doubling is likely to confer distinct advantages to a polyploid. These advantages allow polyploids to thrive in environments that pose challenges to their diploid progenitors (Madlung 2013). For example, Chao et al. (2013) demonstrated that Arabidopsis thaliana first-generation autotetraploids had instantaneously enhanced salt tolerance compared to isogenic diploids. Future studies combining genetics, physiology and ecology should shed light onto the underlying physiological mechanism and its genetic basis of such gains in polyploidy.

Another tetraploid chromosome number was discovered in the present study, $2 n=66$ (Table 2, chromosome group A), in accessions from Heimaey and Stokkseyri, Iceland, and from Kolobrezeg, Poland. This number was also reported for Iceland (Löve \& Löve 1950). Previous reports have shown three tetraploid numbers, 66, 68 and $70(68 \pm 2)$ (Table 1; Rice et al. 2015, eFlora 2020), and they are hereby referred to as cytotypes. The survey of a wide range of species by Wood et al. (2009) has reported that $12-13 \%$ of all angiosperms display some cytotypic variability. The co-existence of variable cytotypes could be facilitated by ecological barriers to gene flow or by numerous biological reproductive barriers which prevent hybridization between proximal cytotypes (Husband \& Sabara 2004). Changes in morphological or physiological characteristics are frequently accompanied by changes in cytotype, often resulting in ecological differentiation between cytotypes (Levin 2002). This might have something to do with the sexual dimorphism and sex chromosome evolution in dioecious species (Charlesworth 2018, 2019). This needs to be investigated, but at least in $H$. peploides sex-specific differences in growth and biomass allocation have been documented (SanchezVillas et al. 2012, 2017).

The present study shows for the first time the presence of B chromosomes in Honckenya, in the accessions from Iceland, i.e. Surtsey, Heimaey and Stokkseyri (Table 2, Figs. 4a and 4f). Supernumerary B chromosomes, as opposed to the standard A chromosomes, are dispensable genetic elements found in hundreds of plant species world-wide (Jones \& Rees 1982). Despite the widespread existence, B chromosomes can occur in some members of the population and are absent in others, most probably due to their irregular and non-mendelian inheritance (Jones \& Houben 2003). The biological significance of $\mathrm{B}$ chromosomes is still inconclusive, but when occurring in low numbers (such as one or two), as in the present study, they tend to be neutral in their phenotypic effects, whereas in high numbers they mostly have a negative effect on the fitness and fertility of the organism (Jones 2018). Nevertheless, recent studies using new and more powerful genomic approaches have begun to show positive effects of plant B chromosomes, for example, in seed germination under drought stress, plant resistance to fungal diseases and plant survival under certain stress conditions (reviewed in Dhar et al. 2019). The presence of B chromosomes in the Icelandic accessions of $H$. peploides may be an advantage in the species colonization in extreme environments. 
Diploid $(2 n=2 x=34)$ and triploid $(2 n=3 x=51)$ chromosome numbers exist across the species distribution range

Diploid chromosome number $2 n=2 x=34$ and triploid number $2 n=3 x=51$ (including group $\mathrm{D}, 2 n=50-52$ ) are discovered in the present study (Table 2). The diploid number has been documented by Probatova (2004), but the triploid number is reported here for the first time. The diploid number was discovered in one accession from Heimaey (Hp-07, Fig. 4e). On the other hand, the triploid number was detected in two accessions from Heimaey, Hp-05 (Fig. 4d) and Hp07, accession Hp-09 from Surtsey, accession Hp-06 from Miquelon Island, Canada, and accession Hp-28, which may be from the nearby Madeleine Islands or from a locality in Europe (the plant label showing origin was lost). Furthermore, the presence of only one satellite (NOR bearing) chromosome in triploid cells (e.g. Fig. 4d) confirms that the cells are triploid, as a tetraploid cell has two satellite chromosomes, or one pair (Fig. 3b).

Our study, therefore, presents two important findings about the diploid $H$. peploides. Firstly, the diploid number is no longer unique to the subspecies major, but also exists in the subspecies diffusa/peploides. Secondly, these two localities are geographically different and distant from one another (oceanic islands: Russia-Moneron in the North Pacific versus Iceland-Heimaey in the North Atlantic). This diploid form is probably an ancient relict of the once wide spread species. The whole genome duplication (WGD) event, giving rise to the present-day autotetraploid species, might have happened somewhere before the tetraploid species became widespread, by colonizing new habitats, new islands, and coastal regions, thus replacing the diploid progenitors. The genetic divergence, resulting in geographical and taxonomical variation at the subspecies level, might have taken place during the species radiation, colonization and establishment in a new environment. The alternative scenario is that the WGD event in $H$. peploides had occurred independently multiple times and in different diploid populations. This can only be answered with more research on phylogeographical aspects of this species on a global scale. However, ecological modeling of the temporal evolution of a diploid-autopolyploid system associated with WDG commonly supports patterns of adaptive niche differentiation in polyploids, with young polyploids often invading new niches and leaving their diploid progenitors behind (Baduel et al. 2018). In this respect, the former scenario for H. peploides, i.e. WGD before tetraploid radiation, seems more likely.

The present study shows that the occurrence of the triploid number $2 n=3 x=51$ (including group $\mathrm{D}$, $2 n=50-52$ ) is more frequent than that of the diploid number. In Iceland, the triploid number was found in accessions from Surtsey and Heimaey, but outside Iceland it was detected at least from Miquelon Islands in the Atlantic on the eastern coast of Canada. In all these locations and the surrounding islands and nearby coastal regions, tetraploids are common (Table 2). In Heimaey, both diploid and tetraploid plants coexist. Populations on the southern shores of the island of Moneron (at the north-eastern end of the Sea of Japan) were found to be diploid $(2 n=34)$ (Probatova 2004), however populations from the nearby island of Sakhalin (only about 30 nautical miles northeast of Moneron Island) were found to be tetraploid with three cytotypes $(2 \mathrm{n}=66,68,70)$ (Sokolovskaya \& Strelkova 1960). Moreover, populations from the more northerly Wrangle Island were found to be tetraploid and also contained three cytotypes $(2 \mathrm{n}=66,68,70)$ (Goldblatt 1985; Agapova 1993). The triploids must have been formed as offspring of the wide-hybridization between the diploid and the tetraploid plants. Such wide-hybridization may have occurred locally (sympatrically) or within a short dispersal distance during long colonization history of the species. Note that triploid progenies can have different chromosome numbers, depending on cytotypes of the tetraploid parent - they can be $2 n=51$ $(34+68 / 2), 2 n=50(34+66 / 2)$, or $2 n=52(34+70 / 2)$. All these three triploid numbers were discovered in the present study (Table 2).

Triploid hybrids play an important role in plant species evolution, especially in the maintenance of the evolutionary dynamics of mixed-ploidy populations (Husband 2004, Anamthawat-Jónsson 2019). Triploid hybrids themselves are normally not able to expand into a sizable population outcompeting the parental accessions or species, due mainly to the loss of fertility following aberrant meiosis of the gamete production. Triploid plants are known to be less fertile than individuals with even numbers of chromosome sets (Stebbins 1971). Difficulties regarding chromosomal pairing and segregation in meiosis make triploids gametophytically unstable, producing a variety of euploid $(1 \mathrm{n}, 2 \mathrm{n}$ or $3 \mathrm{n})$ and 
aneuploid gametes (Husband 2004). Triploids can, however, be partially fertile since they are able to generate some euploid gametes. There is a large difference in triploid fertility among species, with some reported almost completely sterile and others comparatively fertile. The comprehensive survey made by Ramsey \& Schemske (1998) showed that triploid pollen fertility, compiled from 41 studies, ranged from $0 \%$ to $96.5 \%$, with a mean pollen fertility of $31.9 \%$ in triploid angiosperms. Seed set was observed in ten studies, whereas lack of seed setting was observed in seven studies. To sum up, a triploid hybrid normally has a low level of fertility, or in other words, a high level of sterility. This balance functions as a reproduction barrier preventing a hybrid from increasing its population size thus displacing the parental species or population, but keeping its fertility down to the level that maintains a stable hybrid zone, where the two hybridizing taxa (in our case in the diploid-autotetraploid system) are able to coexist across all levels of ecological selection (see review in Wolf et al. 2001, Ramsey \& Schemske 2002). As with $H$. peploides, triploid hybrids are likely to function as a bridge to gene flow, facilitating the fixation of tetraploids in a new environment.

\section{Aneuploids are common in Honckenya peploides}

Aneuploid cells are characterized by incomplete chromosome sets. The present study reveals for the first time numerous chromosome numbers that are categorized as aneuploids, arranged here in groups (Table 2) for the discussion purposes: groups B (6064); C (54-58); E (44-48) and F ( 40). Groups B and $\mathrm{C}$ lie between tetraploid and triploid levels, whereas groups $\mathrm{E}$ and $\mathrm{F}$ are between triploid and diploid levels. Two examples of group E are shown in Fig. 4: $2 n=48$ from Surtsey (Fig. 4 b) and $2 n=44$ from Alaska (Fig. 4e).

In the present study, aneuploidy is rather common. It also appears to be more prevalent on oceanic islands than on mainland coastal regions, but this needs further study covering a larger sample size and more location diversity. In contrast, previous reports show that similar aneuploid numbers in Honckenya are relatively rare. Most interestingly, the number $2 n \sim 40$ that was discovered by Áskell and Doris Löve was obtained from an Icelandic material, of unknown origin, however (Löve \& Löve 1956). Malling (1957) reported a somatic chromosome number of $2 n=68$ for $H$. peploides, after re-examining material from the Baltic Sea. He had received this material from Rohweder, who reported chromosome numbers as low as $2 n=48$ in the same material. Observations from the present study coincide with those reports, suggesting that there might be a cytotype of $H$. peploides with approximately 48 to 50 chromosomes.

Where did aneuploid numbers in $H$. peploides come from, and how? At this point it is necessary to define aneuploidy further. According to Ramsey \& Schemske (1998) the term aneuploid refers to a variety of cytotypes, ranging from those which are very similar to euploids (the "hypo-" and "hypereuploids", such as $2 x+1$, a hyper-diploid, and $4 x-1$, a hypo-tetraploid), to those with several to many chromosome additions or deletions (e.g. $2 x+4,4 x$ 3 ). Other papers define the near-euploid aneuploidy more specifically, and the most common terms are trisomic-monosomic for $2 x \pm 1$ and tetrasomicnullisomic for $2 x \pm 2$ aneuploids (e.g. Birchler 2013). The best known case in human cytogenetics is the trisomy 21 (with 3 copies of chromosome no. 21) that causes Down syndrome (Hassold \& Hunt 2001). But plants tolerate aneuploidy much better (Birchler 2013). In some cases, aneuploid cultivars are even more popular among growers than euploid plants, for example aneuploid tulip cultivars with new colours and flower forms (Marasek-Ciolakowska et al. 2014). In wheat breeding, numerous chromosome addition and substitution lines have been produced via widecrossing between wheat and its wild relatives, in an effort to transfer agronomically important traits to the crop species (e.g. Schwarzacher et al. 1992, Andersson et al. 2015). In the case of H. peploides, the tetraploid cytotypes with $2 n=4 x=68 \pm 2$ discussed in the previous section are a good example of the hypo- and hyper-tetraploid cytotypes.

Aneuploidy with suchsmalldeviation(e.g. \pm 2 )from its euploid number may have been the consequence of a mistake in cell division, such as non-disjunction chromosome behavior at the anaphase stage of meiosis-I, or due to chromosome elimination during the metaphase alignment, especially in the embryonic stage of growth (Birchler 2013). Aneuploidy can result from chromosomal rearrangements during an evolutionary time (Mandakova \& Lysak 2018). But the most probable route of aneuploid formation is via inter-ploidy hybridization and back-crossing (Ramsey \& Schemske 1998, Ramana \& Jacobsen 2003, Henry et al. 2010). Interestingly, aneuploids which are produced this way are those with several 
to many chromosome additions or deletions. In the case of $H$. peploides, these are the aneuploids in groups B, C, E and F. They are the intermediate steps towards euploid/tetraploid fixation - they are the cost of polyploidization. Aneuploid plants themselves are considered inferior to their euploid counterparts in numerous ways. Many aneuploids have low viability and fertility (Ramsey \& Schemske 1998) and are low in plant productivity and biomass (Birchler 2013). Aneuploid individuals of Arabidopsis thaliana exhibited diverse phenotypes affecting a wide variety of traits associated with growth rate, plant morphology, flowering and flower traits (Henry et al. 2010). Aneuploids may not be evolutionarily successful due to meiotic problems and genomic imbalance, but they may be different morphologically, which could affect reproduction and pollination preferences, hence becoming a barrier to gene flow (Birchler 2013). The $H$. peploides aneuploids discovered in the present study may play an important role in an ecological and evolutionary context, by maintaining high genetic differentiation and low gene flow within the mixed-ploidy populations. Their inferior fertility is compensated by the species' ability to reproduce asexually, by rhizome spreading and clonal propagation. On Surtsey, the plant can grow and expand into large mat or big clump (Fig. 1). Often daughter clones remain attached to parent clones via rhizomes whose connections sometimes run up to $2 \mathrm{~m}$ from the parent plant (Sánchez-Vilas et al. 2010). The plants are also perennial and long-lived. In this way, $H$. peploides aneuploids are evolutionary successful.

\section{ACKNOWLEDGEMENTS}

This work was partly supported by University of Iceland's Research Fund and ERASMUS Student Exchange Programme. We would like to thank Professor Marianne Philipp and Professor Henning Adsersen, University of Copenhagen, for the samples from Surtsey and Heimaey, and for their supervision and collaboration on the genetic research of this species. We also thank Dr. Borgpór Magnússon and Dr. Sigurður Magnússon, the Icelandic Institute of Natural History, for their knowledge about plant colonization on Surtsey, Dr. Ægir Pór Pórsson and Dr. Lilja Karlsdóttir for their advice on the laboratory work of this project, and we thank all the collaborators who provided seed samples from outside of Iceland.

\section{REFERENCES}

Agapova, N.D.,1993. Chromosome numbers in flowering plants of the flora of the U.S.S.R Moraceae-Zygophyllaceae. Nauka.

Aguilar, R., M. Quesada, L. Ashworth, Y. Herrerias-Diego \& J. Lobo, 2008. Genetic consequences of habitat fragmentation in plant populations: susceptible signals in plant traits and methodological approaches. Mol. Ecol. 17, 5177-5188. DOI: 10.1111/j.1365-294X.2008.03971.x

Al-Shehbaz, I.A. \& S.L. O'Kane, Jr., 2002. Taxonomy and Phylogeny of Arabidopsis (Brassicaceae). The Arabidopsis Book 2002(1), 1-22.

DOI: $10.1199 /$ tab.0001

Anamthawat-Jónsson, K., 2001. Molecular cytogenetics of introgressive hybridization in plants. Methods Cell Sci. 23, 139-148.

DOI: 10.1023/A:1013182724179

Anamthawat-Jónsson, K., 2010. Selected methods in plant cytogenetics. Háskólaprent, Reykjavík, Iceland. ISBN: 9789979-9967-1-2.

Anamthawat-Jónsson, K., 2019. Hybrid introgression: the outcomes of gene flow. Sci. Asia 45, 203-211.

DOI: $10.2306 /$ scienceasia1513-1874.2019.45.203

Andersson, S.C., E. Johansson, M. Baum, F. Rihawi \& E. Bouhssini, 2015. New Resistance Sources to Russian Wheat Aphid (Diuraphis noxia) in Swedish Wheat Substitution and Translocation Lines with Rye (Secale cereale) and Leymus mollis. Czech J. Genet. Plant Breed. 51, 162-165.

DOI: 10.17221/72/2015-CJGPB

Árnason, S.H., Æ.Th. Thórsson, B. Magnússon, M. Philipp, H. Adsersen \& K. Anamthawat-Jónsson, 2014. Spatial genetic structure of the sea sandwort (Honckenya peploides) on Surtsey: an immigrant's journey. Biogeosciences 11, 64956507.

DOI: $10.5194 /$ bg-11-6495-2014

Baduel, P., S. Bray, M. Vallejo-Marin, F. Kolar \& L. Yant, 2018. The "Polyploid Hop": Shifting Challenges and Opportunities over the Evolutionary Lifespan of Genome Duplications. Front. Ecol. Evol. 6, article 117.

DOI: $10.3389 /$ fevo.2018.00117

Baskin, C.C. \& J.M. Baskin, 2001. Seeds: ecology, biogeography, and evolution of dormancy and germination. San Diego, California: Academic Press.

Birchler, J.A., 2013. Aneuploidy in plants and flies: The origin of studies of genomic imbalance. Semin. Cell Dev. Biol. 24, 315-319.

DOI: 10.1016/j.semcdb.2013.02.004.

Brochmann, C., A.K. Brysting, I.G. Alsos, L. Borgen, H.H. Grundt, A.-C. Scheen \& R. Elven, 2004. Polyploidy in arctic plants. Biol. J. Linn. Soc. 82, 521-536.

DOI: $10.1111 / \mathrm{j} .1095-8312.2004 .00337 . \mathrm{x}$ 
Chao, D.Y., B. Dilkes, H.B. Luo, A. Douglas, E. Yabubova, B. Lahner \& D.E. Salt, 2013. Polyploids Exhibit Higher Potassium Uptake and Salinity Tolerance in Arabidopsis. Science 341, 658-659.

DOI: $10.1126 /$ science. 1240561

Charlesworth, D., 2018. Does sexual dimorphism in plants promote sex chromosome evolution? Environ. Exp. Bot. 146, 5-12.

DOI: 10.1016/j.envexpbot.2017.11.005

Charlesworth, D., 2019. Young sex chromosomes in plants and animals. New Phytol. 224, 1095-1107.

DOI: 10.1111/nph.16002

Cires, E., C. Cuesta, E.L. Peredo, M.A. Revilla \& J.A.F. Prieto, 2009. Genome size variation and morphological differentiation within Ranunculus parnassifolius group (Ranunculaceae) from calcareous screes in the Northwest of Spain. Plant Syst. Evol. 281, 193-208.

DOI: $10.1007 / \mathrm{s} 00606-009-0201-9$

Delph, L.F. \& D.E. Wolf, 2005. Evolutionary consequences of gender plasticity in genetically dimorphic breeding systems. New Phytol. 166, 119-128. DOI: $10.1111 / j .1469-8137.2005 .01339 . x$

Dhar, M.K., J. Kour \& S. Kaul, 2019. Origin, Behaviour, and Transmission of B Chromosome with Special Reference to Plantago lagopus. Genes 10, 152.

DOI: $10.3390 /$ genes 10020152

eFloras (2020) 26. Honckenya Ehrhart. Flora of North America, vol. 5, Caryophyllaceae, published on the Internet http://www. efloras.org [accessed 13.01.2020]. Missouri Botanical Garden, St. Louis, MO \& Harvard University Herbaria, Cambridge, MA.

Eithun, A., 2003. Reproduction, genetic variation and responses to temperature increase in populations of Honkenya peploides (L.) Ehrh. in W Greenland, Svalbard and S Norway, M.S. thesis, University of Oslo.

Evans, S.M., A. Verges \& A.G.B. Poore, 2017. Genotypic Diversity and Short-term Response to Shading Stress in a Threatened Seagrass: Does Low Diversity Mean Low Resilience? Front. Plant Sci. 8, article 1417.

DOI: $10.3389 /$ fpls.2017.01417

Flovik, K., 1940. Chromosome Numbers and Polyploidy within the Flora of Spitzbergen. Hereditas 26, 430-440.

Franks, S.J., 2010. Genetics, evolution, and conservation of island plants. J. Plant Biol. 53, 1-9.

DOI: 10.1007/s12374-009-9086-y, 2010.

Friðriksson, S., 1964. The colonization of the dryland biota on the island of Surtsey off the coast of Iceland. Natturufræðingurinn $34,83-89$.

Goldblatt, P., 1985. Index to chromosome numbers 1982-1983. Monogr. Syst. Bot. 13, 224.

Grundt, H.H., R. Obermayer \& L. Borgen, 2005. Ploidal levels in the arctic-alpine polyploid Draba lactea (Brassicaceae) and its low-ploid relatives. Bot. J. Linn. Soc. 147, 333-347.

DOI: $10.1111 / j .1095-8339.2005 .00377 . x$

Haga, T. \& S. Noda, 1976. Cytogenetics of the Scilla scilloides complex.

1. Karyotype, genome, and population. Genetica 46, 161-176.

DOI: $10.1007 / \mathrm{BF} 00121032$

Hassold, T. \& P. Hunt, 2001. To err (meiotically) is human: the genesis of human aneuploidy. Nat. Rev. Genet. 2, 280-291. DOI: $10.1038 / 35066065$

Hauvermale, A.L., L. Amber \& C.M. Steber, 2020. GA signaling is essential for the embryo-to-seedling transition during Arabidopsis seed germination, a ghost story. Plant Sig. Behav. 15, e1705028.

DOI: 10.1080/15592324.2019.1705028.

Henry, I.M., B.P. Dilkes, E.S. Miller, D. Burkart-Waco \& L. Comai, 2010. Phenotypic Consequences of Aneuploidy in Arabidopsis thaliana. Genetics 186, 1231-U288.

DOI: $10.1534 /$ genetics. 110.121079

Houle, G., 1997. No evidence for interspecific interactions between plants in the first stage of succession on coastal dunes in subarctic Quebec, Canada. Can. J. Bot. 75, 902-915.

DOI: $10.1139 / \mathrm{b} 97-100$

Hultén, E., 1971. The circumpolar plants. II. Dicotyledons. K. Sven. Vetenskapsakademiens Handl. 13, 1-463.

Husband, B.C., 2004. The role of triploid hybrids in the evolutionary dynamics of mixed-ploidy populations. Biol. J. Linn. Soc. 82, 537-46. DOI: $10.1111 / \mathrm{j} .1095-8312.2004 .00339 . x$

Husband, B.C. \& H.A. Sabara, 2004. Reproductive isolation between autotetraploids and their diploid progenitors in fireweed, Chamerion angustifolium (Onagraceae). New Phytol. 161, 703-713.

DOI: $10.1046 / j .1469-8137.2004 .00998 . x$

Johnson, A.W. \& J.G. Packer, 1968. Chromosome numbers in the flora of Ogotoruk Creek, N.W. Alaska. Bot. Not. 121, 403-456.

Jones RN (2018) Transmission and drive involving parasitic B chromosomes. Gene 9, 288.

DOI: $10.3390 /$ genes 9080388

Jones, N. \& A. Houben, 2003. B chromosomes in plants: escapees from the A chromosome genome? Trends Plant Sci. 9, 417-23. DOI: $10.1016 / \mathrm{S} 1360-1385(03) 00187-0$

Jones, R.N. \& H.B. Rees, 1982. B chromosomes, Academic Press, London.

Jonsell, B, (2001. Flora Nordica: Chenopodiaceae to Fumariaceae. Bergius Foundation, the Royal Swedish Academy of Sciences. Kapralov, M.V., M. Stift, \& D.A. Filatov, 2009. Evolution of genome size in Hawaiian endemic genus Schiedea (Caryophyllaceae). Trop. Plant Biol. 2, 77-83.

DOI: 10.1007/s12042-009-9029-2

Kim, S., D. Lee \& A.L. Rayburn, 2015. Analysis of Active Nucleolus Organizing Regions in Polyploid Prairie Cordgrass 
(Spartina pectinata Link) by Silver Staining. Cytologia 80, 249-258.

DOI: $10.1508 /$ cytologia. 80.249

Kim, S.Y., K.M. Warpeha \& S.C. Huber, 2019. The brassinosteroid receptor kinase, BRI1, plays a role in seed germination and the release of dormancy by cold stratification. J. Plant Physiol. 241, article 153031 .

DOI: 10.1016/j.jplph.2019.153031.

Leitch, I.J. \& M.D. Bennett, 1997. Polyploidy in angiosperms. Trends Plant Sci. 2, 470-476.

DOI: 10.1016/S1360-1385(97)01154-0

Leitch, A.R. \& I.J. Leitch, 2008. Perspective - Genomic plasticity and the diversity of polyploidy plants. Science $320,481-83$. DOI: $10.1126 /$ science. 1153585

Leitch, I.J., E. Johnston, J. Pellicer, O. Hidalgo \& M.D. Bennett, 2019. Angiosperm DNA C-values database (release 9.0, Apr 2019) https://cvalues.science.kew.org/

Levin, D.A., 2002. The role of chromosomal change in plant evolution. Oxford University Press, Oxford, New York. ISBN 0-19-513860-0

Löve, Á. \& D. Löve, 1950. Some innovations and nomenclatural suggestions in the Icelandic flora. Bot. Not. 24-60.

Löve, Á. \& D. Löve, 1956. Cytotaxonomical conspectus of the Icelandic Flora. Acta Horti Gotob. 20, 65-291.

Löve, Á. \& D. Löve D, 1975. Cytotaxonomical Atlas of the Arctic Flora, J. Cramer, Vaduz, Germany.

Löve, Á. \& D. Löve, 1982. In IOPB chromosome number reports LXXX. Taxon 31, 324-368.

Lövkvist, B. \& U.M. Hultgård, 1999. Chromosome numbers in south Swedish vascular plants. Opera Bot. 137, 1-42.

Lu, Q., Z.S. Zhang, R.T. Zhan \& R. He, 2018. Proteomic analysis of Zanthoxylum nitidum seeds dormancy release: Influence of stratification and gibberellins. Ind. Crop. Prod. $122,7-15$.

DOI: 10.1016/j.indcrop.2018.05.044.

Madlung, A., 2013. Polyploidy and its effect on evolutionary success: old questions revisited with new tools. Heredity 110, 99-104.

DOI: $10.1038 /$ hdy.2012.79

Magnússon, B., S.H. Magnússon \& S. Friðriksson, 2009. Developments in plant colonization and succession on Surtsey during 1999-2008. Surtsey Res. 12, 57-76.

Magnusson, B., S.H. Magnusson, E. Olafsson \& B.D. Sigurdsson, 2014. Plant colonization, succession and ecosystem development on Surtsey with reference to neighbouring islands. Biogeosciences 11, 5521-5537.

DOI: $10.5194 /$ bg-11-5521-2014

Malling, H., 1957. The chromosome number of Honckenya peploides (L.) Ehrh., with a note on its mode of sex determination, Hereditas 43, 517-524,

DOI:10.1111/j.1601-5223.1957.tb03454.x
Mandakova, T. \& M.A. Lysak, 2018. Post-polyploid diploidization and diversification through dysploid changes. Curr. Opin. Plant Biol. 42, 55-65.

DOI: $10.1016 /$ j.pbi.2018.03.001

Mandakova, T., H. Thorbjornsson, R. Pisupati, I. Reichardt, M.A. Lysak \& K. Anamthawat-Jonsson, 2017. Icelandic accession of Arabidopsis thaliana confirmed with cytogenetic markers and its origin inferred from whole-genome sequencing. Iceland Agric Sci. 30, 29-38.

DOI: 10.16886/IAS.2017.03

Marasek-Ciolakowska, A., S.L. Xie, P. Arens \& J.M. van Tuyl, 2014. Ploidy manipulation and introgression breeding in Darwin hybrid tulips. Euphytica 198, 389-400. DOI: $10.1007 /$ s10681-014-1115-3.

McKeown, P.C. \& P.J. Shaw, 2009. Chromatin: linking structure and function in the nucleolus. Chromosoma 118, 11-23.

DOI: $10.1007 / \mathrm{s} 00412-008-0184-2$

Murray, D.F. \& S. Kelso, 1997. Chromosome numbers and notes on the taxonomy of selected Alaskan vascular plants. Rhodora $99,33-55$.

Otto, S.P. \& J. Whitton, 2000. Polyploid incidence and evolution. Annu. Rev. Genet. 34, 401-437.

DOI: 10.1146/annurev.genet.34.1.401

Packer, J.G. \& G.D. McPherson, 1974. Chromosome numbers in some vascular plants from northern Alaska. Can. J. Bot. 52, 1095-1099. DOI: $10.1139 / \mathrm{b} 74-138$

Pederson, T., 2011. The nucleolus. Cold Spring Harbor Perspectives in Biology 3, a000638.

Philipp, M. \& H. Adsersen, 2014. Colonization of an empty island: how does a plant with a plastic gender system respond? Biogeosciences 11, 6657-6665.

DOI: $10.5194 /$ bg-11-6657-2014

Probatova, N., V. Barkalov \& E. Rudyka, 2004. Chromosome Numbers of Selected Vascular Plant Species from Sakhalin, Moneron and the Kurile Islands. Bull. Hokkaido Univ. Mus. 2, 15-23.

Ramana, M.S. \& E. Jacobsen, 2003. Relevance of sexual polyploidization for crop improvement - A review. Euphytica 133, 3-18.

DOI: $10.1023 / \mathrm{A}: 1025600824483$.

Ramsey, J. \& D.W. Schemske, 1998. Pathways, mechanisms, and rates of polyploidy formation in flowering plants. Annu. Rev. Ecol. Evol. Syst. 29, 467-501.

DOI: 10.1146/annurev.ecolsys.29.1.467

Ramsey, J. \& D.W. Schemske, 2002. Neopolyploidy in flowering plants. Annu. Rev. Ecol. Syst. 33, 589-639. DOI: 10.1146/annurev.ecolsys.33.010802.150437

Ramsey, J., A. Robertson \& B. Husband, 2008. Rapid adaptive divergence in new world Achillea, an autopolyploid complex of ecological races. Evolution 62, 639-653.

DOI: $10.1111 / \mathrm{j} .1558-5646.2007 .00264 . x$ 
Rice, A., L. Glick, S. Abadi, M. Einhorn, N.M. Kopelman \& et al., 2015 The Chromosome Counts Database (CCDB) - a community resource of plant chromosome numbers. New Phytologist 206, 19-26.

DOI: $10.1111 / \mathrm{nph} .13191$

Rogers, S.O. \& A.J. Bendich, 1987. Ribosomal ENA genes in plants: variability in copy number and in the intergenic spacer. Plant Mol Biol. 9, 509-520.

DOI: $10.1007 / \mathrm{BF} 00015882$

Sanchez Vilas, J. \& R. Retuerto, 2017. Sexual dimorphism in water and nitrogen use strategies in Honckenya peploides: timing matters. J. Plant Ecol. 10, 702-712.

DOI: 10.1093/jpe/rtw072

Sanchez-Vilas, J., R. Bermudez \& R. Retuerto, 2012. Soil water content and patterns of allocation to below- and above-ground biomass in the sexes of the subdioecious plant Honckenya peploides. Ann. Bot. 110, 839-848.

DOI: $10.1093 / \mathrm{aob} / \mathrm{mcs} 157$

Sanchez-Vilas, J., M. Philipp \& R. Retuerto, 2010. Unexpectedly high genetic variation in large unisexual clumps of the subdioecious plant Honckenya peploides (Caryophyllaceae). Plant Biol. 12, 518-525

Schwarzacher, T., K. Anamthawat-Jónsson, G.E. Harrison \& et al., 1992. Genomic in situ hybridization to identify alien chromosomes and chromosome segments in wheat Theor. Appl. Genet. 84, 778-786.

DOI: $10.1007 / \mathrm{BF} 00227384$

Sigurdsson, B.D. \& B. Magnusson, 2010. Effects of seagulls on ecosystem respiration, soil nitrogen and vegetation cover on a pristine volcanic island, Surtsey, Iceland. Biogeosciences 7, 883-891.

DOI: $10.5194 / \mathrm{bg}-7-883-2010$

Sokolovskaya, A.P. \& O.S. Strelkova, 1960. Geograficheskogo rasprostranenie poliploidnykh idov rasteniy $\mathrm{v}$ evraziatskoy arktike. Bot. Zhurn. 45, 370-381.

Soltis, P.S. \& D.E. Soltis, 2000. The role of genetic and genomic attributes in the success of polyploids. Proc. Natl. Acad. Sci. 97, 7051-7057.

DOI: 10.1073/pnas.97.13.7051

Soltis, P.S., D.B. Marchant, Y. Van de Peer, \& D.E. Soltis, 2015. Polyploidy and genome evolution in plants. Curr. Opin. Genet. Dev. 35, 119-125.

DOI: 10.1016/j.gde.2015.11.003

Soltis, D., P. Soltis, D. Schemske, J. Hancock, J. Thomson, B. Husband $\&$ W. Judd, 2007. Autopolyploidy in angiosperms: have we grossly underestimated the number of species? Taxon 56, 13-30.

DOI: $10.2307 / 25065732$

Stebbins GL (1971) Chromosomal Evolution in Higher Plants, J. W. Arrowsmith Ltd, Bristol, UK.

Stuessy, T.F., 2009. Plant taxonomy: the systematic evaluation of comparative data. New York: Columbia University Press.
Suda, J., R. Malcová, D. Abazid, M. Banaš, F. Procházka, O. Šída \& M. Štech, 2004. Cytotype distribution in Empetrum (Ericaceae) at various spatial scales in the Czech Republic. Folia Geobot. 39, 161-171.

DOI: $10.1007 / \mathrm{BF} 02805244$

Thompson, J.N. \& H.F. Merg, 2008. Evolution of polyploidy and the diversification of plant-pollinator interactions. Ecology 89, 2197-2206

DOI: $10.1890 / 07-1432.1$

Tsukui, T. \& T. Sugawara, 1992. Dioecy in Honckenya peploides var. major (Caryophyllaceae). Bot. Mag. 105, 615-624. DOI: 10.1007/BF02489435

Voronkova, N.M., E.V. Burkovskaya, T.A. Bezdeleva \& O.L. Burundukova, 2011a. Morphological and biological features of plants related to their adaptation to coastal habitats. Russ. J. Ecol. 39, 1-7.

Voronkova, N.M., V.P. Verkholat \& A.B. Kholina, 2011b. Specific features of plants at early stages of the colonization of loose volcanic matter. Biology Bull. 38, 237-241. DOI: $10.1134 / \mathrm{S} 1062359011030150$

Whittaker, R.J., K.A. Triantis, \& R.J. Ladle, 2008. A general dynamic theory of oceanic island biogeography, J. Biogeogr. 35, 977-994

DOI: $10.1111 / \mathrm{j} .1365-2699.2008 .01892 . x$

Wolf, D.E., N. Takebayashi \& L.H. Rieseberg, 2001. Predicting the risk of extinction through hybridization. Conserv Biol 15:1039-1053.

DOI: $10.1046 / j .1523-1739.2001 .0150041039 . x$

Wood, T.E., N. Takebayashi, M.S. Barker, I. Mayrose, P.B. Greenspoon \& L.H. Rieseberg, 2009. The frequency of polyploid speciation in vascular plants. Proc. Natl. Acad. Sci. $106,13875-13879$

DOI: $10.1073 /$ pnas.0811575106

Yang, B., J. Cheng, J. Wang, Y. Cheng, Y. He, H. Zheng \& Z. Wang, 2019. Physiological characteristics of cold stratification on seed dormancy release in rice. Plant Growth Regul. 89, 131-141. DOI: 10.1007/s10725-019-00516-Z

Yuan, N., H.P. Comes, Y.R. Mao, X.S. Qi \& Y.X. Qiu, 2012. Genetic effects of recent habitat fragmentation in the Thousand-Island Lake region of southeast China on the distylous herb Hedyotis chrysotricha (Rubiaceae). Am. J. Bot. 99, 1715-1725. DOI: 10.3732/ajb.1200054

Zhukova, P.G., 1966. Chromosome numbers in some species of plants of the northeastern part of the U.S.S.R. Bot. Zhurn. 51, $1511-1516$ 